\title{
Antioxidant Potential and its Correlation with the Contents of Phenolic Compounds and Flavonoids of Methanolic Extracts from Different Medicinal Plants
}

\author{
Teixeira, T. S.; Vale, R. C.; Almeida, R. R.; Ferreira, T. P. S.; Guimarães, L. \\ G. L.*
}

Rev. Virtual Quim., 2017, 9 (4), 1546-1559. Data de publicação na Web: 26 de julho de 2017

http://rvq.sbq.org.br

\begin{abstract}
Potencial Antioxidante e sua Correlação com os Teores de Compostos Fenólicos e Flavonoides dos Extratos Metanólicos de Diferentes Plantas Medicinais
\end{abstract}

Resumo: Neste estudo, os extratos metanólicos de dez espécies de plantas medicinais coletadas em Gurupi, Tocantins, Brasil, foram submetidos aos ensaios de neutralização dos radicais ABTS e DPPH, redução do ferro (FRAP) e poder redutor, para investigação do potencial antioxidante. Os resultados revelaram que as plantas avaliadas apresentam pronunciadas atividades antioxidantes, sendo as espécies Buchenavia tetraphylla, Buchenavia tomentosa e Lippia sidoides as que apresentaram as maiores atividades, bem como os maiores teores de compostos fenólicos e de flavonoides. Por meio da determinação dos coeficientes de Person, foi possível observar correlação entre os teores de compostos fenólicos e as atividades antioxidantes perante todos os ensaios. Por outro lado, não foram observadas correlações satisfatórias entre os teores de flavonoides e tais atividades, sugerindo que os compostos fenólicos são os principais contribuintes para o potencial antioxidante apresentado pelos extratos das plantas medicinais estudadas.

Palavras-chave: Buchenavia; Lippia sidoides; Ensaios antioxidantes.

\begin{abstract}
In this study, methanolic extracts of ten species of medicinal plants collected at Gurupi, Tocantins state, Brazil, were subjected to assays of neutralization of ABTS and DPPH radicals, ferric reducing antioxidant power (FRAP), and reducing power to investigate their antioxidant potential. The results revealed that the plants that were investigated exhibited strong antioxidant activities. The species Buchenavia tetraphylla, Buchenavia tomentosa, and Lippia sidoides displayed the highest activities, as well as the largest contents of phenolic compounds and flavonoids. Using Pearson's correlation coefficient, we could observe correlations between the contents of phenolic compounds and the antioxidant activities in all the assays. On the other hand, we could not observe satisfactory correlations between the flavonoid contents and these activities, which suggest that the phenolic compounds provide the main contributions to the antioxidant potential displayed by the medicinal plant extracts that were studied.
\end{abstract}

Keywords: Buchenavia; Lippia sidoides; Antioxidant assays.

* Federal University of São João del-Rei, Natural Science Department, Dom Bosco Campus, CEP 36301160, São João del Rei-MG, Brazil.

Miguimaraes@ufsj.edu.br

DOI: 10.21577/1984-6835.20170090

Rev. Virtual Quim. |Vol 9| |No.4| |1546-1559| 


\section{Antioxidant Potential and its Correlation with the Contents of Phenolic Compounds and Flavonoids of Methanolic Extracts from Different Medicinal Plants}

\section{Tallyta S. Teixeira, ${ }^{b}$ Renata Cássia do Vale, ${ }^{a}$ Regiamara R. Almeida, ${ }^{\text {a }}$ Talita P. S. Ferreira, ${ }^{b}$ Luiz Gustavo L. Guimarães ${ }^{a}$}

${ }^{a}$ Federal University of São João del-Rei, Natural Science Department, Dom Bosco Campus, CEP 36301160, São João del Rei-MG, Brazil.

${ }^{\mathrm{b}}$ Federal University of Tocantins, Bioprocess and Biotechnology Engineering Department, Gurupi Campus, CEP 77402970, Gurupi-TO, Brazil.

* Iguimaraes@ufsj.edu.br

Recebido em 31 de agosto de 2017. Aceito para publicação em 26 de julho de 2017

\section{Introduction}

2. Material and methods

2.1. Sample collection

2.2. Preparation and solutions of extracts

2.3. Determination of contents of phenolic compounds and flavonoids

2.4. Determination of antioxidant activity by neutralization of ABTS free radicals

2.5. Determination of antioxidant activity by neutralization of DPPH free radicals

2.6. Determination of antioxidant activity by FRAP assay

2.7. Determination of antioxidant activity in terms of reducing power

2.8. Statistical analysis

\section{Results and Discussion \\ 4. Conclusion}

\section{Introduction}

Free radicals and other reactive oxygen and nitrogen species are produced in natural physiological processes by organisms. ${ }^{1}$ Increases in the production of free radicals owing to alterations in metabolic processes can result in oxidative damage to cellular components, such as lipids, proteins, and nucleic acids, which causes serious health problems. $^{2}$ Some studies have pointed out relationships between free radicals and oxidants during the course of many diseases, such as neurodegeneration, cardiovascular diseases, diabetes, cancer, osteoporosis, and premature aging. ${ }^{3}$

Plants contain many molecules that exhibit significant antioxidant activity, that is, the capacity to prevent, stop or reduce 
oxidative damage to different cellular components, such as proteins, lipids, and nucleic acids. ${ }^{4,5}$ Among these molecules, phenolic compounds have received much attention, and it has been demonstrated that they are the main sources of the antioxidant activities displayed by plants. ${ }^{6,7}$

Besides the reducing power of phenolic groups, many others therapeutic activities exhibited by plants, such as anti-HIV activity, the control of diabetes and cardiovascular diseases, and anti-inflammatory and anticarcinogen properties, are related to this class of compounds. ${ }^{8,9}$ In Brazil, there is increasing interest in studying the antioxidant potential of natural compounds, which is mainly due to high biodiversity and the considerable number of plants already used in popular medicine. ${ }^{6}$

There are currently many assays that can be used to determine antioxidant activity in vitro. However, these methods employ distinct mechanisms related to the oxidation process. The utilization of different methodologies therefore becomes mandatory to assess the antioxidant properties of plant extracts with higher precision. ${ }^{10,11}$ Among the methods that have been described, chemical assays based on the ability to scavenge free radicals have been the most widely used because of their facile technique. As examples, the $2,2^{\prime}$ azinobis(3-ethylbenzothiazoline-6-sulfonic

acid) radical cation $\left(\mathrm{ABTS}^{\circ+}\right)$ and diphenylpicrylhydrazyl (DPPH) free radical scavenging methods and the ferric reducing antioxidant power (FRAP) assay are spectrophotometric procedures based on electrons transfer reactions that indirectly measure the antioxidant capacity several types of samples. ${ }^{12,13}$

In this context, it is possible to perceive the great importance of antioxidant substances and the possible relationships between the antioxidant activities and phenolic compounds. There is also high biodiversity in Brazil, for example in the Tocantins' savanna, which contains many plants that are used in popular medicine, but few studies of their therapeutic potential have been carried out. Therefore, this study aimed to determine the antioxidant potential of methanolic extracts of plants used in local medicine (Gurupi, Tocantins). Their antioxidant activities were measured by different tests, namely, neutralization of ABTS and DPPH radicals, FRAP assays, and tests of reducing power, and the resulting values were correlated with the contents of phenolic compounds and flavonoids to determine possible relationships between them.

\section{Material and methods}

\subsection{Sample collection}

Samples of ten species of plants that are used in local popular medicine were collected at Gurupi, Tocantins, Brazil. The plants that were studied are listed in Table 1.

The parts of the plants used to obtain the extracts were the leaves, with the exception of the species Buchenavia tomentosa, from which the bark of the trunk was used.

Table 1. Data for the plants used to obtain extracts

\begin{tabular}{|c|c|c|c|}
\hline Species & Popular Name & Collection Date & Location \\
\hline $\begin{array}{c}\text { Buchenavia tomentosa } \\
\text { Eichler }\end{array}$ & "Mirindiba" & October 4, & $11{ }^{\circ} 42^{\prime} 23^{\prime} \mathrm{S}$ \\
& & 2013 & $49^{\circ} 03^{\prime} 51^{\prime} \mathrm{W}$ \\
\hline Buchenavia tetraphylla & "Mirindiba" & September 24, & $11^{\circ} 34^{\prime} 47^{\prime} \mathrm{S}$ \\
(Aubl.) R.A. Howard & & 2013 & $48^{\circ} 57^{\prime} 54^{\prime} \mathrm{W}$ \\
\hline
\end{tabular}




\begin{tabular}{|c|c|c|c|}
\hline Mentha pulegium L. & "Poejo" & $\begin{array}{c}\text { October 26, } \\
2013\end{array}$ & $\begin{array}{l}\text { 114' } 45.9 " \mathrm{~S} \\
49 \circ 03 \text { '10.3"W }\end{array}$ \\
\hline $\begin{array}{l}\text { Lippia sidoides Cham., } \\
\text { thymol chemotype }\end{array}$ & "Alecrim pimenta" & November 9, 2013 & $\begin{array}{l}11^{\circ} 44^{\prime} 48^{\prime \prime} \mathrm{S} \\
49^{\circ} 02^{\prime} 55^{\prime \prime} \mathrm{W}\end{array}$ \\
\hline $\begin{array}{l}\text { Lippia sidoides Cham., } \\
\text { carvacrol chemotype }\end{array}$ & "Alecrim pimenta" & November 9, 2013 & $\begin{array}{l}11^{\circ} 44^{\prime} 32^{\prime \prime S} \\
49^{\circ} 03^{\prime} 22^{\prime \prime} \mathrm{W}\end{array}$ \\
\hline $\begin{array}{c}\text { Brosimum gaudichaudii } \\
\text { Trecul }\end{array}$ & $\begin{array}{l}\text { “Inharé"; “Mama } \\
\text { cadela" }\end{array}$ & $\begin{array}{l}\text { December 12, } \\
2013\end{array}$ & $\begin{array}{l}11^{\circ} 43^{\prime} 49^{\prime \prime} \mathrm{S} \\
49^{\circ} 01^{\prime} 44^{\prime \prime} \mathrm{W}\end{array}$ \\
\hline Cissus sicyoides L. & "Insulina vegetal" & $\begin{array}{l}\text { March 15, } \\
2014\end{array}$ & $\begin{array}{l}11^{\circ} 43^{\prime} 39^{\prime \prime} \mathrm{S} \\
49^{\circ} 04^{\prime} 27^{\prime \prime} \mathrm{W}\end{array}$ \\
\hline $\begin{array}{c}\text { Acmella oleracea (L.) R. K. } \\
\text { Jansen }\end{array}$ & "Jambú" & $\begin{array}{c}\text { April 15, } \\
2014\end{array}$ & $\begin{array}{l}11^{\circ} 44^{\prime} 46^{\prime \prime S} \\
49^{\circ} 02^{\prime} 58^{\prime \prime} \mathrm{W}\end{array}$ \\
\hline $\begin{array}{c}\text { Arrabidaea chica (Humb. \& } \\
\text { Bonpl.) B. Verl. }\end{array}$ & "Pariri" & $\begin{array}{c}\text { January 22, } \\
2014\end{array}$ & $\begin{array}{l}11^{\circ} 44^{\prime} 25^{\prime \prime S} \\
49^{\circ} 03^{\prime} 39^{\prime \prime} \mathrm{W}\end{array}$ \\
\hline $\begin{array}{c}\text { Hyptis glomerata Mart. ex } \\
\text { Schrank }\end{array}$ & “Pau-da-vitória” & $\begin{array}{c}\text { November } 27 \\
2013\end{array}$ & $\begin{array}{l}11^{\circ} 44^{\prime} 35^{\prime \prime S} \\
49^{\circ} 02^{\prime} 52^{\prime \prime} \mathrm{W}\end{array}$ \\
\hline
\end{tabular}

\subsection{Preparation and solutions of extracts}

After collection, the plant materials were dried in the shade at the ambient temperature. Later, they were crushed and subjected to extraction by maceration with cold methanol. About $100 \mathrm{~g}$ plant material was used with $2.0 \mathrm{~L}$ solvent in each extraction process, which continued for 7 days. After this period, the mixtures were filtered and the resulting solutions were subjected to rotoevaporation to remove excess solvent. Then, the extracts were freeze-dried and stored at 4 ㅇ. .

For subsequent analysis, solutions of the extracts were prepared in ethanol/water (1:1) with a concentration of $1 \mathrm{~g} \mathrm{~L}^{-1}$ (1000 ppm).

2.3. Determination of contents of phenolic compounds and flavonoids
The content of phenolic compounds was determined by the Folin-Ciocalteu spectrophotometric method using an adaptation of the methodology described by Zhou et al. (2009). ${ }^{14}$ An aliquot $(50 \mu \mathrm{L})$ of a plant extract $\left(1 \mathrm{~g} \mathrm{~L}^{-1}\right.$ in ethanol/water [1:1]) or a standard solution of gallic acid $(10,25$, 50,75 , and $100 \mathrm{ppm}$ ) was added to $5 \mathrm{~mL}$ distilled water, and $500 \mu \mathrm{L}$ Folin-Ciocalteu reagent $(1 \mathrm{M})$ was added to the mixture, which was then shaken. After 5 minutes, 500 $\mu \mathrm{L}$ sodium carbonate solution (20\%) was added to the mixture. After incubation for 1 hour at room temperature in the absence of light, the absorbance was measured at 765 $\mathrm{nm}$ with a spectrophotometer (Biospectro SP-220). A reagent blank was prepared using distilled water. The results were expressed as $\mathrm{mg}$ gallic acid/g extract.

The content of flavonoids was also determined by a spectrophotometric method using quercetin as a reference following the methodology described by Carpes et al. (2008). ${ }^{15}$ An aliquot $(500 \mu \mathrm{L})$ of a plant extract $\left(1 \mathrm{~g} \mathrm{~L}^{-1}\right.$ in ethanol/water, [1:1]) or a 
standard solution of quercetin $(5,10,25,50$, 75 , and $100 \mathrm{ppm}$ ) was added to $4.3 \mathrm{~mL}$ ethanol (99.8\% P.A.), and $100 \mu \mathrm{L}$ aluminum nitrate solution (10\%) and $100 \mu \mathrm{L}$ sodium acetate solution $(1 \mathrm{M})$ were added to the mixture, which was then shaken. A reagent blank was prepared using distilled water instead of aluminum nitrate. After incubation for 40 minutes at room temperature in the absence of light, the absorbance was measured at $415 \mathrm{~nm}$ with a spectrophotometer (Biospectro SP-220). The results were expressed as mg quercetin/g extract.

\subsection{Determination of antioxidant activity by neutralization of ABTS free radicals}

For the determination of antioxidant activity by the method employing the diammonium salt of the ABTS radical, an adaptation of the methodology described by Re et al. (1999) was used. ${ }^{16}$ The ABST radical was prepared by the reaction of $5 \mathrm{~mL}$ of the ABTS solution $(7 \mathrm{mM})$ with $88 \mu \mathrm{L}$ potassium persulfate solution $(140 \mathrm{mM})$, in which the combined solution was kept at room temperature in the absence of light for 16 hours. Subsequently, the solution was diluted with ethanol, until it exhibited an absorbance of 0.70 at a wavelength of $734 \mathrm{~nm}$, using a spectrophotometer (Biospectro SP-220). To determine the antioxidant potentials of the different extracts, four dilute solutions were prepared from a $1 \mathrm{~g} \mathrm{~L}^{-1}$ solution of each extract in ethanol/water 1:1. A $30 \mu \mathrm{L}$ aliquot of each dilute extract solution was transferred to a test tubes containing $3.0 \mathrm{~mL}$ of the ABTS radical solution. After 6 minutes, the absorbance was measured at a wavelength of $734 \mathrm{~nm}$. Synthetic trolox was utilized as a standard solution at concentrations of 100,500,1000, 1500 and $2000 \mu \mathrm{M}$ in ethanol, and the results were expressed as $\mu \mathrm{mol}$ trolox/g extract.

2.5. Determination of antioxidant activity by neutralization of DPPH free radicals
The determination of antioxidant activity by the DPPH free radical scavenging assay was conducted in accordance with an adaptation of the methodology described by Moura-Rufino et al. (2007). ${ }^{17}$ A solution of each extract was obtained with a concentration of $1 \mathrm{~g} \mathrm{~L}^{-1}$ ethanol/water (1:1), $f$ which five dilute solutions were prepared with concentrations of $0.01,0.05,0.10,0.15$ and $0.20 \mathrm{~g} \mathrm{~L}^{-1}$. A $0.1 \mathrm{~mL}$ aliquot of each dilute extract solution was transferred to a test tube containing $3.9 \mathrm{~mL}$ of a solution of DPPH radical $(60 \mu \mathrm{M})$, and $0.1 \mathrm{~mL}$ ethanol was utilized as a control. Readings of the absorbance at $515 \mathrm{~nm}$ were made every minute and monitored until they stabilized. From the results, the reaction time needed for each plant extract to consume $50 \%$ of the $\mathrm{DPPH}$ present $\left(\mathrm{EC}_{50}\right.$ time) was determined. The readings for the samples were accompanied by readings for the initial control. The results, which were expressed as g extract/g DPPH, were determined from an analytical curve for DPPH at concentrations of $10,20,30,40,50$ and $60 \mu \mathrm{M}$. Methanol was used as a blank, and all the readings were performed at $515 \mathrm{~nm}$ using a spectrophotometer (Biospectro SP-220).

\subsection{Determination of antioxidant activity by FRAP assay}

Assays of antioxidant activity by the FRAP method were conducted in accordance with the methodology employed by Pulido et al. (2000), with alterations. ${ }^{18}$ Initially, solutions of acetate buffer $(0.3 \mathrm{M}, \mathrm{pH} 3.6), 2,2,6$-tris(2pyridyl)-1,3,5-triazine (TPTZ) (10 $\mathrm{mM})$, and ferric chloride $(20 \mathrm{mM})$ were prepared. Subsequently, at FRAP reagent was prepared from combination of $25 \mathrm{~mL}$ acetate buffer solution, $2.5 \mathrm{~mL}$ TPTZ solution, and $2.5 \mathrm{~mL}$ ferric chloride solution. To enable the analyses, different extract solutions in ethanol/water (1:1) were prepared with concentrations of 1,3 and $5 \mathrm{~g} \mathrm{~L}^{-1}$ according to the antioxidant activity of each plant. From these solutions, four new solutions were prepared with different concentrations. An 
aliquot of $90 \mu \mathrm{L}$ of each dilute extract solution was transferred to a test tube, and then $270 \mu \mathrm{L}$ distilled water and $2.7 \mathrm{~mL}$ FRAP reagent were added. The resulting solution was kept in a water bath (37 ㅇ) for 30 minutes. Subsequently absorbance readings were performed at $595 \mathrm{~nm}$ with a spectrophotometer (Biospectro SP-220). The FRAP reagent was used as a blank. To obtain the results, which were expressed as $\mu \mathrm{mol}$ iron (II) sulfate/g methanolic extract, analyses were carried out utilizing different concentrations of $500,1000,1500$, and 2000 $\mu \mathrm{M}$ ferric sulfate in distilled water.

\subsection{Determination of antioxidant activity in terms of reducing power}

The reducing power of the extracts was determined using ascorbic acid as a reference in accordance with the method used by Yen and Chen (1995), with alterations. ${ }^{19}$ The reaction solution was prepared by mixing $1 \mathrm{~mL}$ dilute extract solutions $\left(1,3\right.$ and $\left.5 \mathrm{~g} \mathrm{~L}^{-1}\right)$ in ethanol/water (1:1), $2.5 \mathrm{~mL}$ phosphate buffer solution $(0.2$ $\mathrm{M}, \mathrm{pH}$ 6.6), and $2.5 \mathrm{~mL}$ potassium ferricyanide solution (1\%). The resulting combined solution was heated to 50 으 for 20 minutes. Then, $2.5 \mathrm{~mL}$ trichloroacetic acid $(10 \%)$ was added, and the resulting mixture was centrifuged at $3000 \mathrm{rpm}$ for 10 minutes. Then, an aliquot of $2.5 \mathrm{~mL}$ was taken from the upper layer of each solution, to which 2.5 $\mathrm{mL}$ distilled water and $0.5 \mathrm{~mL}$ ferric chloride solution $(0.1 \%)$ were added. The absorbance of the resulting solution was measured at 700 $\mathrm{nm}$ using a spectrophotometer (Biospectro SP-220). Ascorbic acid was used as a standard solution at concentrations of $10,25,50,75$ and $100 \mathrm{mg} \mathrm{L}^{-1}$ in distilled water. The results were expressed as mg ascorbic acid/g extract.

\subsection{Statistical analysis}

All the analyses were conducted in triplicate. Analyses of variance were performed to determine the variations between each plant species in terms of the contents of active compounds and antioxidant activities. The Scott-Knott test (5\%) was used to compare average effects. All the analyses were carried out using SISVAR software. ${ }^{20}$ Pearson's correlation coefficient was determined to establish the relationship between the antioxidant activity and the contents of phenolic compounds and flavonoids.

\section{Results and Discussion}

The flavonoids contents found in the extracts of the studied plants are present in Figure 1.

Among the species that had the highest flavonoid contents in their extracts are the two chemotypes of $L$. sidoides which had contents of $87.52 \pm 2.43 \mathrm{mg}$ quercetin/g extract for the thymol chemotype, and 61.04 $\pm 2.94 \mathrm{mg}$ quercetin/g extract for the carvacrol chemotype. These were followed by the species in the genus Buchenavia, which were also prominent in terms of their flavonoid contents, which were $41.22 \pm 1.47$ and $23.63 \pm 2.28 \mathrm{mg}$ quercetin/g extract for $B$. tomentosa and B. tetraphylla, respectively. For $L$. sidoides, phytochemical studies have already demonstrated the presence of flavonoids such as cirsimaritin, luteolin, flavones, quercetin, and taxifolin in its leaves. $^{21}$ 


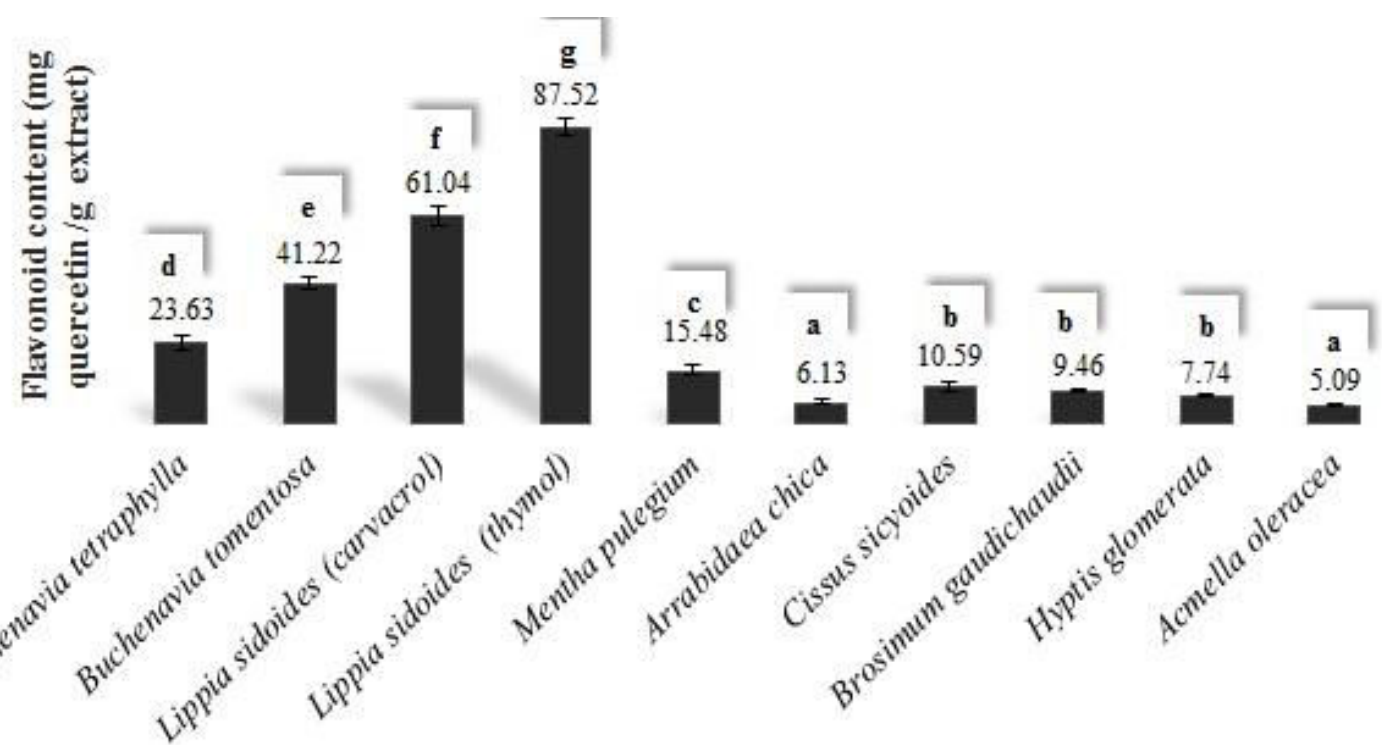

Figure 1. Flavonoids contents of methanolic extracts of ten species of medicinal plants. The order of the letters corresponds to an increase in the values. Mean values followed by the same letter are not significantly different by the Scott-Knott test $(P<0.05)$

All the methanolic extracts of the studied plants contained considerable amounts of phenolic compounds, and significant differences were observed between the average amounts for the different studied species (Figure 2).

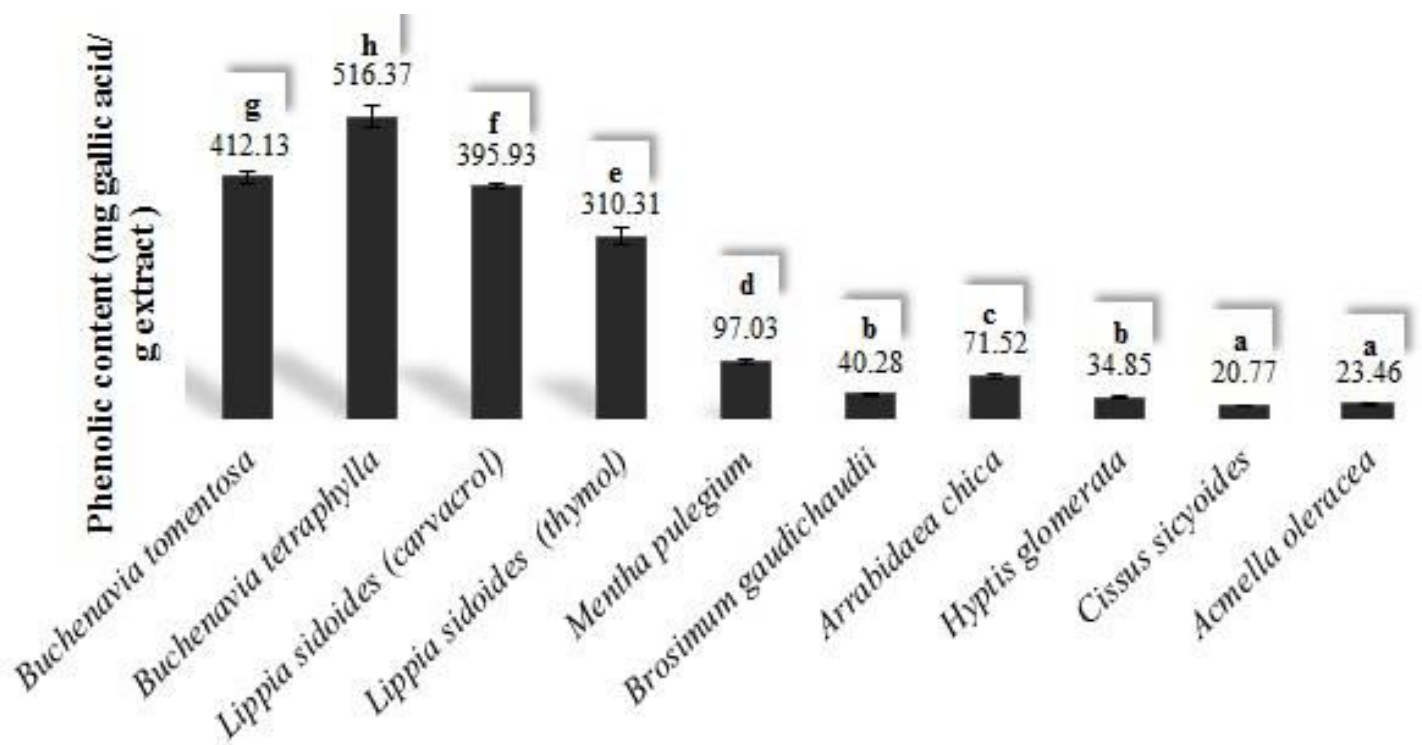

Figure 2. Contents of phenolic compounds of methanolic extracts of ten species of medicinal plants. The order of the letters corresponds to an increase in the values. Mean values followed by the same letter are not significantly different by the Scott-Knott test $(P<0.05)$

Tawaha et al. (2007), when determining the antioxidant activity and total phenolics content of Jordan's plant species, estimated that a total phenolics content of greater than
$20 \mathrm{mg}$ gallic acid equivalent/g dry weight of extract can be considered to be high. On the basis of this result, all ten studied extracts must be considered to be promising sources 
of phenolic compounds. The most prominent contents, which were found in the species of the genus Buchenavia, were $516.37 \pm 19.22$ and $412.13 \pm 11.12 \mathrm{mg}$ gallic acid/g extracts for B. tetraphylla and B. tomentosa, respectively. As others authors have also shown, extracts of carvacrol and thymol chemotypes of $L$. sidoides had high contents of phenolic compounds of $395.93 \pm 3.69$ and $310.31 \pm 15.14 \mathrm{mg}$ gallic acid/g extract, respectively. ${ }^{22}$

The contents of phenolic compounds found in $B$. tomentosa (barks) and $B$. tetraphylla (leaves) in this study (Figure 2) are similar to those found in an ethanolic extract of the leaves of Terminalia fagifolia (439.38 \pm $3.15 \mathrm{mg}$ gallic acid/g sample), which belongs to the same family (Combretaceae) as the genus Buchenavia, which demonstrates the potential of the studied species in terms of their phenolic content. ${ }^{23}$

Studies carried out of methanolic extracts of the leaves of ten Lippias species collected in the state of Minas Gerais demonstrated that the total content of phenolic compounds varied between 105.5 and $255.4 \mathrm{mg}$ tannic $\mathrm{acid} / \mathrm{g}$ extract, which indicated that phenolic compounds were responsible for the antioxidant power exhibited by the plant extracts. $^{24}$ These contents are lower than those found in the methanolic extracts of the two studied chemotypes of $L$. sidoides (Figure 2), which emphasizes the potential of these two types of plant as a source of phenolic compounds in relation to other Lippia species.

The best results obtained from the ABTS radical scavenging assay were those for $B$. tomentosa (7018.00 $\mathrm{mmol}$ trolox/g extract) and B. tetraphylla $(5225.33 \mu \mathrm{mol}$ trolox/g extract), as can be observed in Figure 3 . The two chemotypes of $L$. sidoides also exhibited antioxidant activities that were relevant but statistically different, but with values about that were about half of those displayed by the Buchenavia species, as the activity exhibited by the carvacrol chemotype was $3369.67 \mu \mathrm{mol}$ trolox/g extract and that exhibited by the thymol chemotype was $2404.00 \mu \mathrm{mol}$ trolox/g extract. The extracts of the other species exhibited antioxidant activities that were lower than $1000 \mu \mathrm{mol}$ trolox/g extract, as can be observed in Figure 3.

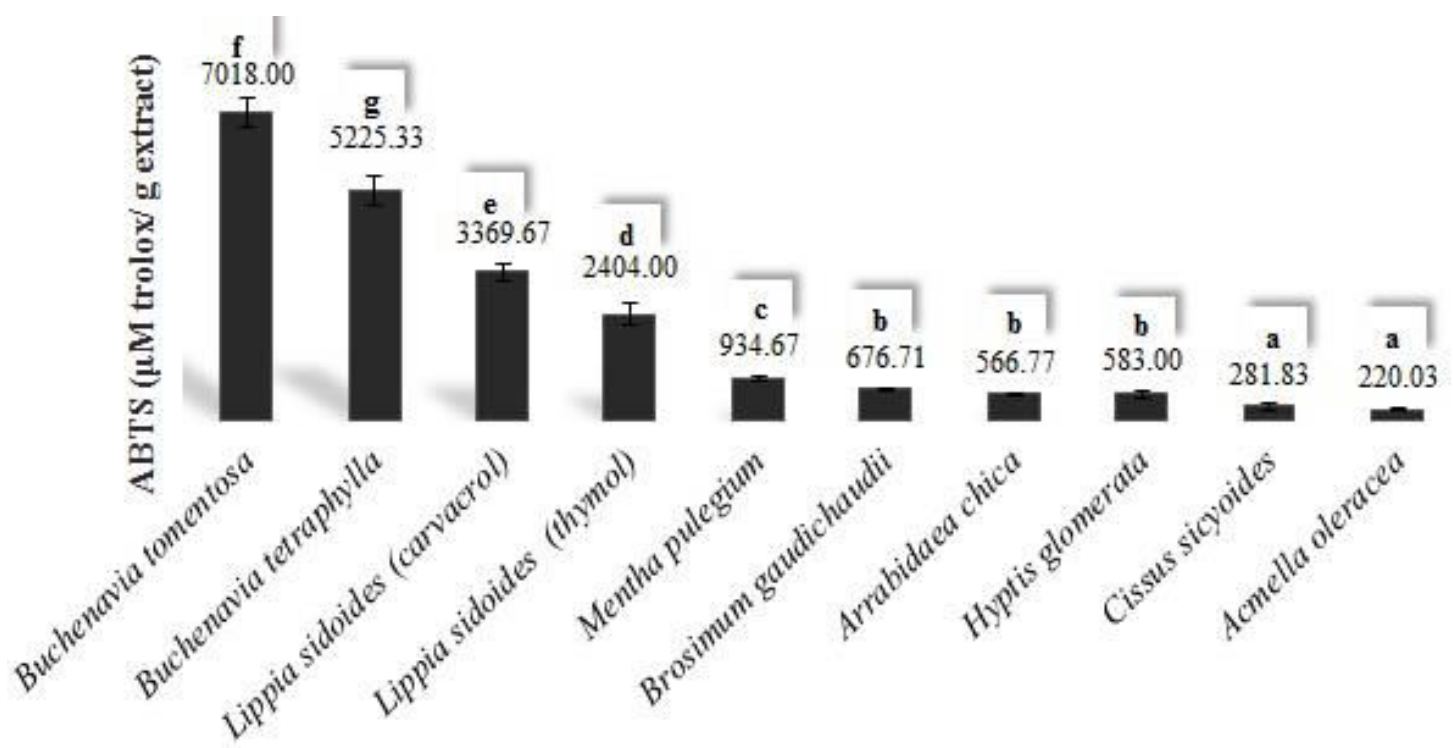

Figure 3. Antioxidant activities of methanolic extracts of ten species of medicinal plants, determined by an ABTS radical scavenging. The order of the letters corresponds to an increase in the values. Mean values followed by the same letter are not significantly different by the Scott-Knott test $(P<0.05)$ 
Rajurkar and Hande (2011), when determining the antioxidant activity of ethanolic extracts of traditional Indian medicinal plants, using an ABTS radical scavenging assay, observed contents of $650 \pm$ 0.05 (Cyperus rotundus), $1110 \pm 0.08$ (Pterocarpus marsupium) and $1430 \pm 0.09$ (Tribulus terrestris) $\mu \mathrm{g}$ trolox equivalent/g dry weight. These values are lower than those exhibited by some of the studied species (Figure 3), which emphasizes the potential for neutralizing free radicals of the studied plants, in particular B. tomentosa, B. tetraphylla, and the two chemotypes of $L$. sidoides. ${ }^{25}$

In a similar way to the results observed in the ABTS radical scavenging assay, the plants of the genus Buchenavia also exhibited higher antioxidant activity in the DPPH free radicals scavenging assay (Figure 4). It was confirmed that among all the studied species, B. tetraphylla exhibited the highest capacity to neutralize DPPH radicals, in other words, the lowest value of the $g$ extract/g DPPH ratio.

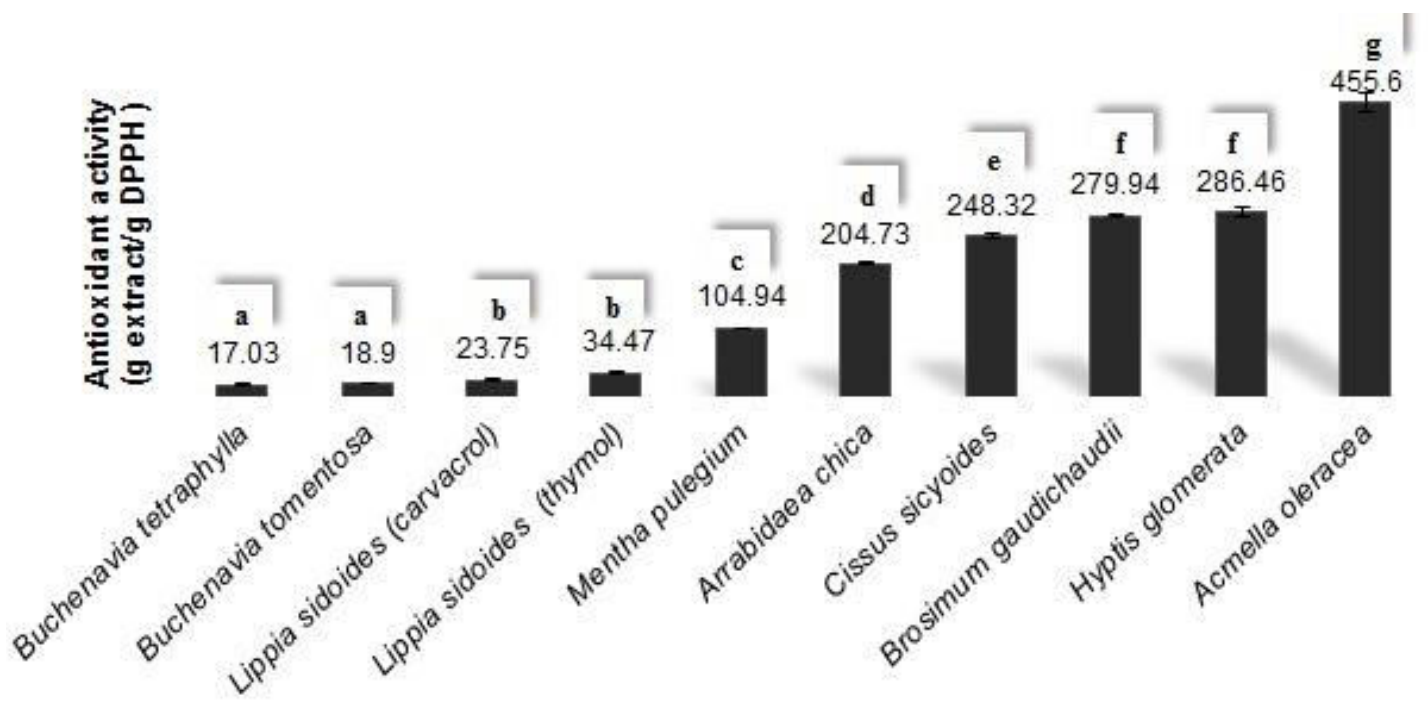

Figure 4. Antioxidant activities of methanolic extracts of ten species of medicinal plants determined by a DPPH radical scavenging assay. The order of the letters corresponds to an increase in the values. Mean values followed by the same letter are not significantly different by the Scott-Knott test $(P<0.05)$

These results are in accordance with those found by Ahmed et al. (2014), who using the same assay, confirmed the great antioxidant potential presented by three species of the genus Combretum, (which also belong to the Combretaceae family) C. woodii $(38.87 \mathrm{~g} / \mathrm{L})$, C. padoides $(44.47 \mathrm{~g} / \mathrm{L})$, and C. bracteosum $(57.27 \mathrm{~g} / \mathrm{L}){ }^{26}$

The extract that could reduce the greatest amount of ferric ions was that of $B$. tetraphylla, followed by $B$. tomentosa, which had values of 7566.336 and $7530.00 \mu \mathrm{mol}$ iron(II) sulfate/g extract, respectively, followed by the two chemotypes of $L$. sidoides, which had values of 3668.00 (carvacrol chemotype) and 3082.67 (thymol chemotype) $\mu \mathrm{mol}$ iron(II) sulfate/g extract, as shown in Figure 5. 


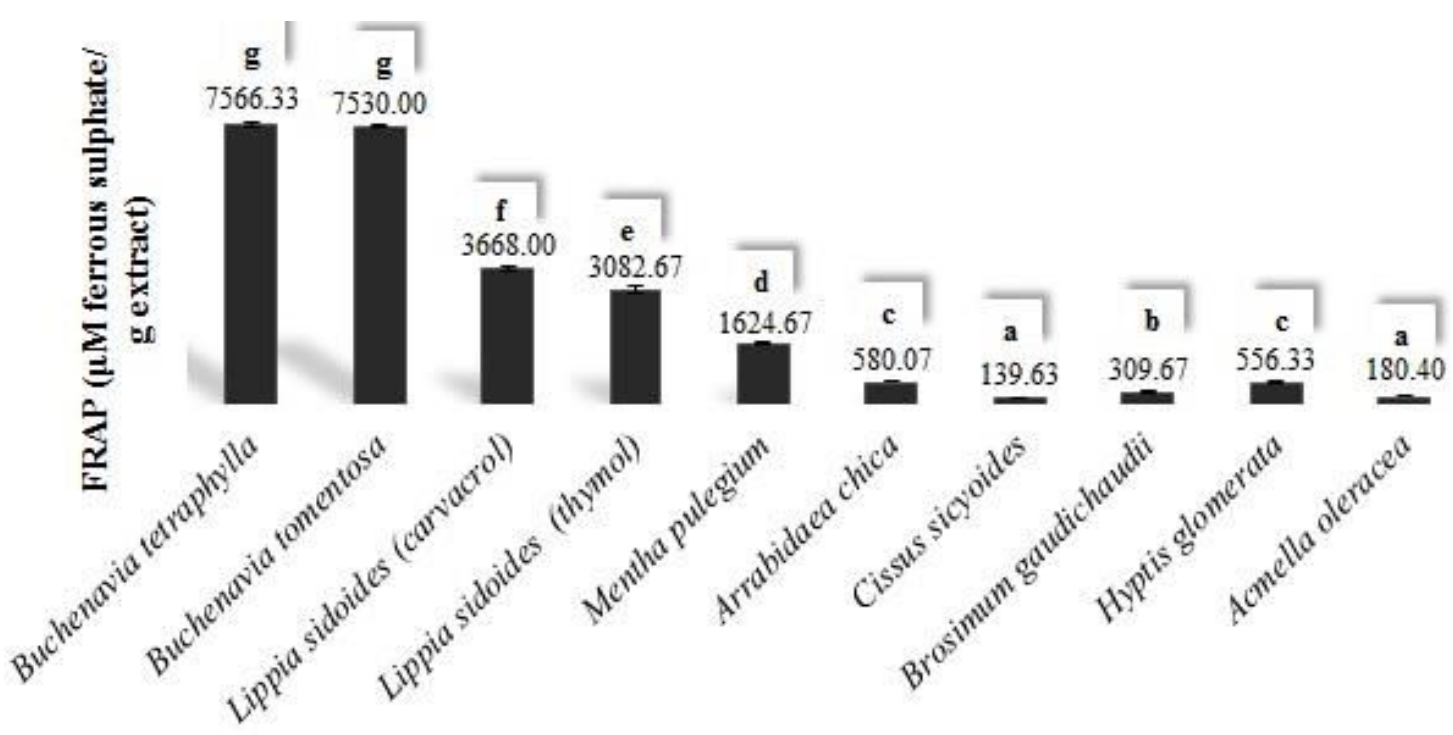

Figure 5. Antioxidant activities of methanolic extracts of ten species of medicinal plants determined by an FRAP assay, obtained through the ferric reducing antioxidant power (FRAP) assay. The order of the letters corresponds to an increase in the values. Mean values followed by the same letter are not significantly different by the Scott-Knott test $(P<0.05)$

Teixeira et al. (2016), in studies investigated the antioxidant potential of ten aqueous extracts of medicinal plants commercialized in the region of the Brazilian Pampas by an FRAP method, determined contents that varied between $65.416 \pm 23.0$ (Malva parviflora) and $5.636 \pm 13.0$ (Equisetum sp.) $\mu \mathrm{mol}$ of iron(II) sulfate/100 g extract. ${ }^{27}$ These results are lower than those found for the majority of the species investigated in this study.

The reducing power of the $B$. tetraphylla $\left(695.37 \mathrm{mg} \mathrm{g}^{-1}\right)$ was superior to that of the extract of B. tomentosa $\left(631.42 \mathrm{mg} \mathrm{g}^{-1}\right)$, followed by $L$. sidoides (carvacrol chemotype) (260.83 $\mathrm{mg} \mathrm{g}^{-1}$ ) and L. sidoides (thymol chemotype) (233.40 $\mathrm{mg} \mathrm{g}^{-1}$ ), of which both displayed relevant results (Figure 6).

Fabri et al. (2011), when investigating the antioxidant activity of the Lippias species most widely used in Brazilian popular medicine via an assay of reducing power, proved that all the extracts exhibited a significant reducing power when compared with an ascorbic acid control. ${ }^{28}$ The values found for L. pseudo-thea, L. hermannoides, $L$. alba, $L$. rubella, and $L$. sidoides indicated significant reducing power of $243,127,110$, 109 and $107 \mu \mathrm{g} \mathrm{mL}^{-1}$, respectively, in relation to the already established reducing power of ascorbic acid $\left(105 \mu \mathrm{g} \mathrm{mL}^{-1}\right)$.

In virtue of the potential of polyphenols to act as reducing agents, these extracts are considered to be strong antioxidants. ${ }^{6}$ Using Pearson's correlation coefficient, which quantifies the linear association between two quantitative variables, it was possible to estimate the relationships between the different antioxidant activities of the extracts and their contents of phenolic compounds and flavonoids. ${ }^{29}$ 


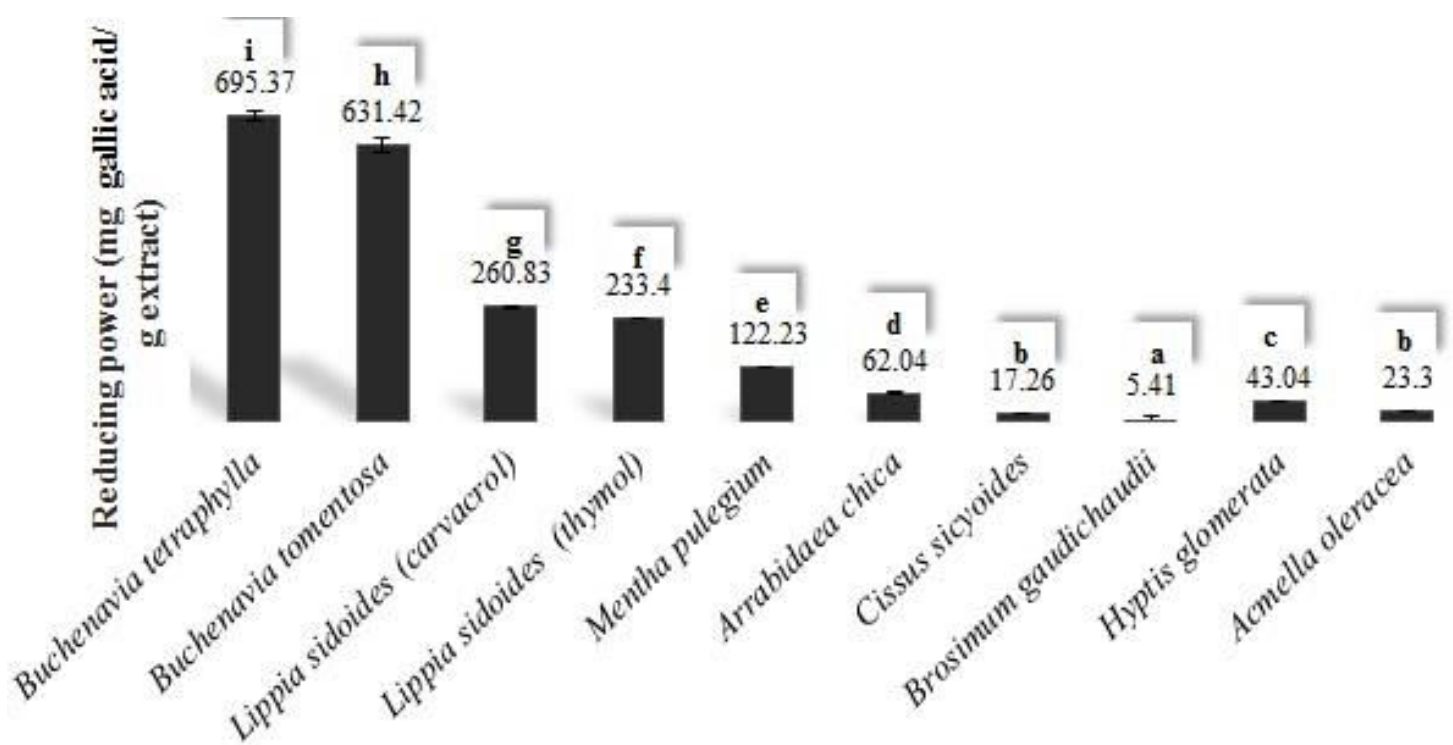

Figure 6. Reducing power of methanolic extracts of ten species of medicinal plants. The order of the letters corresponds to an increase in the values. Mean values followed by the same letter are not significantly different by the Scott-Knott test $(P<0.05)$

The results revealed excellent correlations between the antioxidant activities of the different extracts and their contents of phenolic compounds in ABTS scavenging assays $(r=0.912)$, FRAP assays $(r=0.944)$, assays of reducing power $(r=0.922)$, and DPPH scavenging assays $(r=-0.848)$. The negative correlation coefficient indicates that the lower is the value of the gextract/g DPPH ratio, the higher is the phenolics content, as they are inversely proportional, which is in accordance with the experimental data. The correlation coefficients that were determined indicate that the antioxidant activities possessed by the extracts may be principally caused by the phenolic compounds present in the samples.

A significant correlation between the content of phenolic compounds in plants and the antioxidant activity displayed by the plants has been observed in other studies. Chaudhari and Mahajan (2015), who studied ethanolic extracts of 20 Indian medicinal plants, including Terminalia arjuna, $T$. bellirica, and T. chebula., which belong to the same family (Combretaceae) as the genus Buchenavia, observed that the correlation coefficients were 0.911 and 0.943 between the content of phenolic compounds and the reducing power, and ability to neutralize
DPPH radicals, respectively. ${ }^{30} \mathrm{~A}$ relevant correlation coefficient of $r=-0.82$ between the phenolics content and the antioxidant activity, as determined by at DPPH scavenging assay, was also observed by Quiroga et al. (2013) when they investigated the essential oils of oregano and Lippia turbinata. ${ }^{31} \quad$ Significant correlation coefficients $(r=0.852$ and 0.996$)$ were also observed between the results obtained by FRAP assays and ABTS scavenging assays, respectively, and the total contents of phenolic compounds of extracts of Teminalia catappa, which also belongs to the Combretaceae family. ${ }^{32}$

On the other hand, in this study an inferior correlation was observed between the flavonoid contents and the antioxidant activities of the extracts. The correlation coefficient determined for the assay of reducing power was low $(r=0.399)$, as the extracts that exhibited the highest reducing capacity were of $B$. tetraphylla and $B$. tomentosa, whereas the highest flavonoid contents were found in the extracts of the thymol and carvacrol chemotypes of $L$. sidoides. The same situation was observed when the correlation was investigated between the flavonoid contents and the antioxidant activities as determined using the 
FRAP assays and ABTS scavenging assays, and the correlation coefficients were found to be 0.470 and 0.491 , respectively.

These results are in accordance found by Chaudhari and Mahajan (2015), who while studying methanolic extracts of 20 Indian medicinal plants, also observed a low correlation coefficient (0.346) between flavonoid contents and reducing power, as well as between flavonoid contents and antioxidant activity as determined by the neutralization of DPPH radicals $(0.451) .^{30}$ However, among the methods utilized in this study for the determination of antioxidant activity, the neutralization of DPPH free radicals gave rise to a stronger correlation with the flavonoid content, with a value of $r$ $=-0.699$.

Almeida et al. (2010) assumed that the high antioxidant activity displayed by plants of the species L. sidoides, which was determined by at DPPH free radical scavenging assay, is associated with the large amount of flavonoids present in this plant. However, different results were found in this study. ${ }^{33}$ Among the extracts of the studied species, those of plants of the genus Buchenavia exhibited the highest capacity to neutralize DPPH, although the chemotypes of $L$. sidoides had the highest flavonoid contents.

In this way, the results of this study suggest that, besides the flavonoids, other phenolic compounds might be present that make the principal contribution to the antioxidant capacity of the plant extracts studied in this research, because the total flavonoids content exhibited an inferior correlation with the antioxidant activity in comparison with the content of phenolic compounds. In general, the samples with the highest total phenolic contents exhibited the highest antioxidant activities.

\section{Conclusion}

Among the methanolic extracts of the ten species of medicinal plants that were studied, the extracts of $B$. tomentosa, $B$. tetraphylla, and the two chemotypes of $L$. sidoides (thymol and carvacrol) exhibited the highest antioxidant activities and the highest contents of phenolic compounds and flavonoids. The extracts that were investigated did not behave in the same way in all the assays that were employed, and the order of their antioxidant activity was not determined. By determining values of Pearson's correlation coefficient, it was possible to observe a correlation between the antioxidant activities and the contents of phenolic compounds, which indicates that this group of substances is directly involved in such activities. A weaker correlation was observed between the antioxidant activities and the flavonoid contents, which demonstrated that the presence of a considerable amount of these compounds in a plant does not always imply a corresponding antioxidant potential. In this way, the species $B$. tomentosa, $B$. tetraphylla, and $L$. sidoides are highlighted as sources of substances with antioxidant potential.

\section{Acknowledgments}

We thank "Conselho Nacional de Desenvolvimento Científica e Tecnológico" (CNPq), Federal University of Tocantins (UFT) (Project 800285/2012-3), Federal University of São João del-Rei (UFSJ), "Fundação de Amparo á Pesquisa de Minas Gerais" (FAPEMIG) and "Rede Mineira de Química" (RQ-MG) (Project: CEX-RED-0010-14).

\section{References}

${ }^{1}$ Carvalho, A. V.; Cavalcante, M. A.; Santana, C. L.; Alves, R. M. Características físicas, químicas e atividade antioxidante de frutos de matrizes de cajazeira no estado do Pará. Alimentação Nutricional 2011, 22, 45. [Link] 
${ }^{2}$ Aprioku, J. S. Pharmacology of free radicals and the impact of reactive oxygen species on the testis. Journal of Reproduction \& Infertility 2013, 14, 158. [PubMed]

${ }^{3}$ Saeidnia, S.; Abdollahi, M. Toxicological and pharmacological concerns on oxidative stress and related diseases. Toxicology and Applied Pharmacology 2013, 273, 442. [CrossRef] [PubMed]

${ }^{4}$ Jain, N.; Goyal, S.; Ramawat, K. G. Evaluation of antioxidant properties and total phenolic content of medicinal plants used in diet therapy during postpartum healthcare in Rajasthan. International Journal of Pharmacy and Pharmaceutical Sciences 2011, 3, 248. [Link]

${ }^{5}$ Sousa, R. M. F.; Lira, C. S.; Rodrigues, A. O.; Morais, S. A. L.; Queiroz, C. R. A. A.; Chang, R. Atividade antioxidante de extratos de folhas de ora-pro-nóbis (pereskia aculeata mill.) usando métodos espectrofotométricos e voltamétricos. Bioscience Journal 2014, 30 , 448. [Link]

${ }^{6}$ Fernandes, M. R. V.; Dias, A. L. T.; Carvalho, R. R.; Souza, C. R. F.; Oliveira, W. P. Antioxidant and antimicrobial activities of Psidium guajava L. spray dried extracts. Industrial Crops and Products 2014, 60, 39. [CrossRef]

${ }^{7}$ Lizcano, L. J.; Viloria-Bernal, M.; Vicente, F.; Berrueta, L. A.; Gallo, B.; Martínez-Cañamero, M.; Ruiz-Larrea, M. B.; Ruiz-Sanz, J. I. Lipid oxidation inhibitory effects and phenolic composition of aqueous extracts from medicinal plants of colombian amazonia. International Journal of Molecular Sciences 2012, 13, 5454. [CrossRef] [PubMed]

${ }^{8}$ Kumar, S.; Pandey, A. K. Chemistry and biological activities of flavonoids: an overview. The Scientific World Journal 2013, 2013, 1. [CrossRef] [PubMed]

${ }^{9}$ Saibabu, V.; Fatima, Z.; Khan, L. A.; Hameed, $S$. Therapeutic potential of dietary phenolic acids. Advances in Pharmacological Sciences 2015, 2015, 1. [CrossRef] [PubMed]

${ }^{10}$ Souza, T. J. T.; Apel, M. A., Bordignon, S.; Matzenbacher, N. I.; Zuanazzi, J. A. S.; Henriques, A. T.; Composição química e atividade antioxidante do óleo volátil de Eupatorium polystachyum DC. Revista
Brasileira de Farmacognosia 2007, 17, 368. [CrossRef]

${ }^{11}$ Sousa, M. S. B.; Vieira, L. M.; Lima, A. Fenólicos totais e capacidade antioxidante in vitro de resíduos de polpas de frutas tropicais. Brazilian Journal of Food Technology 2011, 14, 202. [CrossRef]

${ }^{12}$ Tiveron, A. P.; Melo, P. S.; Bergamaschi, K. B.; Vieira, T. M. F. S.; Regitano-d'Arce, M. A. B.; Alencar, S. M. Antioxidant activity of Brazilian vegetables and its relation with phenolic composition. International Journal of Molecular Sciences 2012, 13, 8943. [CrossRef]

${ }^{13}$ Bursal, E.; Köksal, E. Evaluation of reducing power and radical scavenging activities of 7 water and ethanol extracts from sumac (Rhus coriaria L.). Food Research International 2011, 44, 2217. [CrossRef]

${ }^{14}$ Zhou, S. H.; Fang, Z. X.; Lü, Y.; Chen, J. C.; Liu, D. H.; Ye, X. G.; Phenolics and antioxidante properties of bayberry (Myrica rubra Sieb. Et Zucc.) pomace. Food Chemistry 2009, 112, 394. [CrossRef]

${ }^{15}$ Carpes, S. T.; Prado, A.; Moreno, I. A. M.; Mourão, G. B.; de Alencar, S. M.; Masson, M. L. Avaliação do potencial antioxidante do pólen apícola produzido na região sul do Brasil. Química Nova 2008, 31, 1660. [CrossRef]

${ }^{16} \mathrm{Re}, \quad$ R.; Pellegrini, N.; Proteggente, A.; Pannala, A.; Yang, M.; Rice-Evans, C. Antioxidant activity applyying an improved ABTS radical cátion decolorization assay. Free Radical Biology \& Medicine 1999, 26, 1231. [CrossRef] [PubMed]

${ }^{17}$ Yepez, B.; Espinosa, M.; Lopez, S.; Bolanos, G. Producing antioxidant fractions from herbaceous matrices by supercritical fluid extraction. Fluid Phase Equilibria 2002, 194, 881. [CrossRef]

${ }^{18}$ Pulido, R.; Bravo, L.; Sara-Calixto, F. Antioxidant activity of dietary as determined by a modified ferric reducing/ antioxidant power assay. Journal Agriculture and Food Chemistry 2000, 48, 3396. [CrossRef] [PubMed]

${ }^{19}$ Yen, G. C.; Chen, H. Y. Antioxidant activity of various tea extracts in relation to their antimutagenicity. Journal Agriculture Food 
Chemistry 1995, 43, 27. [CrossRef]

${ }^{20}$ Ferreira, D. F. Sisvar: a computer statistical analysis system. Ciência e Agrotecnologia 2011, 35, 1039. [CrossRef]

$21{ }^{21}$ L Guimarães, L. G.; Da Silva, M. L.; Reis, P. C.; Costa, M. T.; Alves, L. L. General Characteristics, Phytochemistry and Pharmacognosy of Lippia sidoides. Natural Product Communications 2015, 10, 1861. [PubMed]

${ }^{22}$ Tawaha, K., Alali, F. Q., Gharaibeh, M., Mohammad, M., El-Elimat, T. Antioxidant activity and total phenolic content of selected Jordanian plant species. Food Chemistry 2007, 104, 1372. [CrossRef]

${ }^{23}$ Sousa, C. M. M.; Silva, H. R.; Vieira-Jr., G. M.; Ayres, M. C. C.; Costa, C. L. S.; Araújo, D. S.; Cavalcante, L. C. D.; Barros, E. D. S.; Araújo, P. B. M.; Brandão, M. S.; Chaves, M. $\mathrm{H}$. Fenóis totais e atividade antioxidante de cinco plantas medicinais. Química Nova 2007, 30, 351. [CrossRef]

${ }^{24}$ Singulani, J. L.; Silva, P. S.; Raposo, N. R. B., Siqueira, E. P.; Zani, C. L.; Alves, T. M. A.; Viccini, L. F. Chemical composition and antioxidante activity of Lippia species. Journal of Medicinal Plants Research 2012, 6, 4416. [CrossRef]

${ }^{25}$ Rajurkar, N. S. Hande, S. M. Estimation of phytochemical content and antioxidant activity of some selected traditional Indian medicinal plants. Indian Journal of Pharmaceutical Sciences 2011, 73, 146. [PubMed]

${ }^{26}$ Ahmed, A. S.; McGaw, L. J.; Elgorashi, E. E.; Naidoo, V.; Eloff, J. N. Polarity of extracts and fractions of four Combretum (Combretaceae) species used to treat infections and gastrointestinal disorders in southern African traditional medicine has a major effect on different relevant in vitro activities. Journal of Ethnopharmacology 2014, 154, 339. [CrossRef] [PubMed]
${ }^{27}$ Teixeira, M. P.; Cruz, L.; Franco, J. L.; Vieira, R. B.; Stefenon, V. M. Ethnobotany and antioxidant evaluation of commercialized medicinal plants from the Brazilian Pampa. Acta Botanica Brasilica 2016, 30, 47. [CrossRef]

${ }^{28}$ Fabri, R. L.; Nogueira, M. S.; Moreira, J. R.; Boyzada, M. L. M.; Scio, E. Identification of antioxidante and antimicrobiral compounds of Lippia species by bioautography. Journal of Medicinal Food 2011, 14, 1. [CrossRef] [PubMed]

${ }^{29}$ Lesaffre, E.; Feine, J.; Leroux, B.; Declerck, D. Statistical and Methodological Aspects of Oral Health Research. Jonh Wiley \& Sons Ltd., 2009.

${ }^{30}$ Chaudhari, G. M.; Mahajan, R. T. Comparative Antioxidant Activity of Twenty Traditional Indian Medicinal Plants and its Correlation with Total Flavonoid and Phenolic Content. International Journal of Pharmaceutical Sciences Review and Research 2015, 30, 105. [Link]

${ }^{31}$ Quiroga, P. R.; Grosso, N. R.; Lante, A.; Lomolino, G.; Zygadlo, J. A.; Nepote, V. Chemical composition, antioxidant activity and anti-lipase activity of Origanum vulgare and Lippia turbinata essential oils. International Journal of Food Science and Technology 2013, 48, 642. [CrossRef]

${ }^{32}$ Annegowda, H. V.; Ween Nee, C.; Mordi, M. N.; Ramanathan, S.; Mansor, S. M. Evaluation of Phenolic Content and Antioxidant Property of Hydrolysed Extracts of Terminalia catappa L. Leaf. Asian Journal of Plant Sciences 2010, 9, 479. [CrossRef]

${ }^{33}$ Almeida, M. C. S.; De Alves, L. A.; Souza, L. G. S.; Machado, L. L.; De Matos, M. S C.; De Oliveira, M. C. F.; Lemos, T. L. G.; Braz-Filho, R. Flavonoides e outras substâncias de Lippia sidoides e suas atividades antioxidantes. Química Nova 2010, 33, 1877. [CrossRef] 